\title{
PARTNER INNOVATION COLLABORATION AND MANAGEMENT SUPPORT TOWARD INNOVATION SPEED AND NEW PRODUCT PERFORMANCE IN SMALL MANUFACTURING FIRMS
}

\author{
Fansuri Munawar*)1 and Didi Tarmidi**) \\ *) Faculty of Economic and Business, Universitas Widyatama \\ Jl.Cikutra No. 2014A Bandung 40125, Indonesia
}

\begin{abstract}
The purpose of this study was to examine and analyze the role of partner innovation collaboration and management support on innovation speed, and its implications towards new product performance in small manufacturing firms. This study took samples in the category of small manufacturing firms in the food \& beverage sector, shoes \& bags sector, craft sector, and diverse sector. Then, this study uses primary data using a questionnaire distributed to 95 owners or managers of small manufacturing firms in the Bandung and surrounding areas. Data analysis uses structural equation modeling based on partial least square with the help of SmartPLS 3.0. The results showed that partner innovation collaboration had a positive and significant effect on innovation speed, then management support had a positive and significant effect on innovation speed, then innovation speed had a positive and significant effect on new product performance, most recently the role of partner innovation collaboration also had a positive effect and significant to new product performance. The R-Square calculation results show that partner innovation collaboration and management support influence 0.432 on innovation speed, then partner innovation collaboration and innovation speed have an effect of 0.637 on new product performance. This study implied that small manufacturing firms to utilize an innovation collaboration with partners and allocate more time, effort, thought, costs in the effort to innovation, and be able to create an atmosphere of work together with employees that support innovation activities. Further research is to include moderation variables that support the improvement of new product performance such as absorptive capacity and technological uncertainty.
\end{abstract}

Keywords: management support, partner innovation collaboration, innovation speed, new product performance

\begin{abstract}
Abstrak: Tujuan dari penelitian ini adalah untuk menguji dan menganalisis peran kolaborasi inovasi mitra dan dukungan manajemen pada kecepatan inovasi, dan implikasinya terhadap kinerja produk baru di perusahaan manufaktur kecil. Penelitian ini mengambil sampel dalam kategori perusahaan manufaktur kecil di sektor makanan \& minuman, sektor sepatu \& tas, sektor kerajinan, dan sektor aneka ragam. Kuesioner penelitian dibagikan kepada 95 pemilik atau manajer perusahaan manufaktur kecil di wilayah Bandung dan sekitarnya. Analisis data menggunakan model persamaan struktural berbasis partial least square dengan bantuan SmartPLS 3.0. Hasil penelitian menunjukkan bahwa kolaborasi inovasi mitra berpengaruh positif dan signifikan terhadap kecepatan inovasi, dukungan manajemen berpengaruh positif dan signifikan terhadap kecepatan inovasi, kecepatan inovasi berpengaruh positif dan signifikan terhadap kinerja produk baru, dan yang terakhir peran kolaborasi inovasi mitra juga memiliki efek positif dan signifikan terhadap kinerja produk baru. Hasil perhitungan $R$-Square menunjukkan bahwa mitra kolaborasi inovasi dan dukungan manajemen mempengaruhi 0,432 pada kecepatan inovasi, maka kolaborasi inovasi mitra dan kecepatan inovasi memiliki pengaruh 0,637 pada kinerja produk baru. Studi ini memberikan implikasi terhadap perusahaan manufaktur kecil untuk memanfaatkan kolaborasi inovasi dengan mitra dan mengalokasikan lebih banyak waktu, upaya, pemikiran, biaya dalam upaya inovasi, serta dapat menciptakan suasana kerja bersama dengan karyawan yang mendukung kegiatan inovasi. Penelitian lebih lanjut adalah memasukkan variabel moderasi yang mendukung peningkatan kinerja produk baru seperti kemampuan serap dan ketidakpastian teknologi.
\end{abstract}

Kata kunci: dukungan manajemen, kolaborasi inovasi mitra, kecepatan inovasi, kinerja produk baru

${ }^{1}$ Corresponding author:

Email: fansuri.munawar@widyatama.ac.id 


\section{INTRODUCTION}

Nowadays, the small manufacturing sector is still at the forefront of economic growth in Indonesia. Based on data from BPS (2016), there are around $16.59 \%$ or 4.3 million of total SMEs, most of which are engaged in 5 industrial sectors, namely food and beverage (44.9\%), wood and woven crafts (19.9\%), textiles and apparel $(14.4 \%)$, non-metal minerals such as flour, mica, and others $(6.9 \%)$; and craft $(3.5 \%)$. However, there is a classic problem for small manufacturing firms who often have difficulty facing the expansion of large companies. It is exemplified in the food and beverage industry which is dominated by 128 large companies with a market share of about $65 \%$ of the food and beverage sector in Indonesia (Sidarta et al. 2016). Basically, the main obstacle for small manufacturing firms must be overcome, including the lack of application of technology and innovation in developing new products (Rizal, 2014). Then, if there is no acceleration of innovation for the business, eventually it will die or at least it will be difficult to move forward. Martowardojo (2016) explains that the quality of human resources and technical and non-technical skills in SMEs was still low, the development of new products was still limited, and innovation was low. In line with this opinion, Satari (2014) explains that one of the main obstacles of manufacturing SMEs is the low quality of human resources and innovation. Researchers have proposed several factors that can increase innovation speed, such as partner innovation collaboration (e.g, Fabrizio, 2009; Kim \& Inkpen, 2005; Markman et al. 2005; Wang \& Wang, 2012) and management support (e.g, Carbonell \& Rodríguez, 2009; Hamdi et al. 2016). Furthermore, the researchers also discovered the role of innovation speed in improving new product performance (Carbonell \& Rodríguez, 2010; Shan et al. 2016).

Research on innovation speed in small manufacturing firms, especially in Indonesia, still has received less attention. The role of an innovation collaboration with partners, such as suppliers, distributors, customers, and universities as well as management support for innovation speed and its impact on new product performance is also still rarely researched. Although there are, only one or more variables from this study were examined, such as Hamdi et al. (2016) who examined the role of management support for innovation speed in 147 biotechnology industries in Malaysia, or Shan et al. (2016) who examined the role of innovation speed on new product performance in 153 new companies, or Wang \& Wang (2012) who examined the role of information sharing on innovation speed in 89 hi-tech companies in China. Aside from the different research variables, most of the existing research is large and high-tech companies, only a few researchers in small manufacturing firms.

The term of partner innovation collaboration (PIC) is an interaction between industries with different collaborators, such as suppliers, customers, educational institutions, and competitors who aim to innovate together and develop a new product with combining their resources and capabilities (Kang \& Kang, 2010). The goal of PIC can access resources, technology, information, skills, and abilities to complement each other, learn from partners and ease of access to markets (Cravens \& Piercy, 2013; Hagedoorn, 2002). Collaboration in sharing knowledge and information with partners as valuable elements for innovation (Chiang \& Hung, 2010). The ability of firm to use knowledge and information from innovation collaborations with partners can determine the level of innovation, such as the method of finding new solutions and the speed of innovation in reaction to volatile market demand (Du Plessis, 2007), so that partner innovation collaboration can increase innovation speed (Fabrizio, 2009; Wang \& Wang, 2012). Then, a firm that collaborates on innovation with partners can increase access to resources, gain knowledge transfer, improve the innovation process, reduce development costs, shorten the development cycle, reduce financial risks and target and influence customers who might improve new product performance (Wang et al. 2015).

Management support refers to a large amount of support given by management in developing new products (Carbonell \& Rodríguez-Escudero, 2009). Management support can be in the form of sponsorship, helping the team solve problems, encouraging the team, maintaining open communication channels for those involved in developing new products, simplifying the decision-making process, and providing adequate capital and resources (Carbonell \& RodríguezEscudero, 2009). Management support can influence innovations by providing resources such as human resources, technology, manufacturing, and finance (Griffin, 2011). The product development cycle will not be shorter unless management truly supports the whole of the innovation project (Atkinson et al. 2006). This management support is needed in adopting a 
technological culture for the company (Martín-Rojas et al. 2013). This transformation can change the operational and strategic levels in the company, so that management support is needed in providing the expected value for the company (Cook et al. 2000).

In addition, innovation speed is an essential factor for companies due to the reduced product life cycle period and increased competition caused by technological developments and globalization (Chen et al. 2010). The innovation speed as an essential concept in product development refers to the pace of innovation and commercialization of new product (Carbonell \& Rodríguez Escudero, 2010), and is also described as the company's ability to accelerate activities and tasks through the process of developing new products (Chen et al. 2005). Consequently, innovation speed can respond to rapid changes in the market environment by considering low costs and short time (Chen et al. 2010; Shan et al. 2016).

Based on explanation above, the objectives of this study are 1) analyzing the role of partner innovation collaboration and management support on innovation speed in small manufacturing firms, 2) analyzing the role of innovation speed on new products performance in small manufacturing firms, 3) analyzing the role of partner innovation collaboration on new product performance in small manufacturing firms.

\section{METHODS}

This research uses primary data obtained from respondents by asking them to answer several questions contained in the research instrument. Then, the data source is the owner or manager of small manufacturing firms, which consists of food \& beverages, shoes \& bags, craft, and diverse sectors with convenience sampling method. Then, the target area for the population is Bandung and its surroundings because that area is the center of small manufacturing firms in West Java. The study was conducted from March 2019 to May 2019. The sample size in this study refers to Ghozali (2011), which states that the number of samples can be calculated from the magnitude of the parameters multiplied by 5 to 10 . Because this study uses two exogenous variables and two endogenous variables with a total of 19 parameters, so the required sample in this study a minimum of $19 \times 5=95$ samples.
This data analysis using structural equation modeling based partial least square by SmartPLS 3.0. The research instrument consisted of four questionnaire sections which were adjusted from various sources to collect information on demographics and business characteristics of the respondent's biodata filling instrument, then fill the question in variables of partner innovation collaboration, management support, innovation speed and new product performance contained in the instrument. The five-point Likert scale, indicated by strongly disagree until strongly agree $(1=$ strongly disagree, $5=$ strongly agree), is used to measure the construction of the study. The construction of new product performance items was also evaluated using a five-point Likert scale ( 1 = significantly decreased; 5 = significantly higher). Furthermore, testing the validity and reliability using factor loading, average variance extracted or AVE, convergence validity, discriminant validity, Cronbach's alpha, and composite reliability. Factor loading is intended to ensure that each question item is classified in each variable.

Based on Reseach model (Figure 1) and previous studies conducted by Wang \& Wang (2012), Wang et al. (2015), (Carbonell \& Rodríguez-Escudero, 2009), and Shan et al. (2016) can be hypothesized:

H1: Partner innovation collaboration can positively increase innovation speed in small manufacturing firms.

H2: Management support can positively increase innovation speed in small manufacturing firms.

H3: Innovation speed can positively improve new product performance in small manufacturing firms.

H4: Partner innovation collaboration can positively improve new product performance in small manufacturing firms.

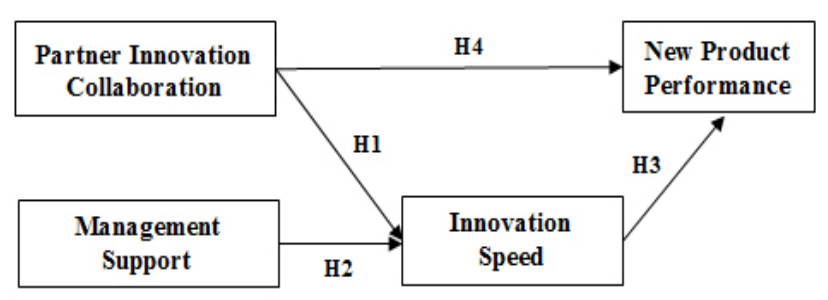

Figure 1. Research model 


\section{RESULTS}

\section{Respondent Profile}

Based on the data result on the respondent profile, a summary of characteristics was obtained. The descriptive of profile in this study show that most respondent $76.8 \%$ or 73 respondents were male, and $23.2 \%$ or 22 respondents were female. The firm's profile in term of employees number, $55.8 \%$ or 53 firms had the number of employees below 5 peoples, $22.1 \%$ or 21 firms was between 5-10 employees, $13.7 \%$ or 13 firms between $11-20$ employees, $4.2 \%$ or 4 firms were between 21-30 employees, and also the remaining $4.2 \%$ or 4 firms were above 30 employees. Then, the firm's profile from time periods in business operation, $35.8 \%$ or 34 firms were between 5-10 years in operation, $25.3 \%$ or 24 firms were above 30 years in operation, $20.0 \%$ or 19 firms were between $21-30$ years in operation, $10.5 \%$ or 10 firms were between $2-5$ years in operation and the remaining $8.4 \%$ or 8 firms were between 11-20 years in operation. The firm's profile in a term of manufacturing category, $37.9 \%$ or 36 firms were in the craft category, $30.5 \%$ or 29 firms were in the diverse category, $21.1 \%$ or 20 firms were in shoes $\&$ bag category, and the remaining $10.5 \%$ or 10 firms were in food \& beverages category. The firm's profile in a term of new product sales (in one year), $30.5 \%$ or 29 firms were below 500 units in new product sales, $23.2 \%$ or 22 firms were above 3000 units in new product sales, $22.1 \%$ or 21 firms were between 1000-2000 units in new product sales, $15.8 \%$ or 15 firms were between 500-1000 units in new product sales, and the remaining $8.4 \%$ or 8 firms were between $2000-3000$ units in new product sales.

\section{Test of Validity}

Measurement of validity test whether the research instrument is valid or not. This test is performed using the SmartPLS 3.0 application program by presenting convergent validity (Table 1). The variables adopted in this research consist of partner innovation collaboration and management support as an independent variable; while the dependent variable is innovation speed and new product performance. The measurement of the validity of each variable based on the evaluation of cross loading factors using convergent validity. Each factor loading $>0.7$. Based on the validity test results, all indicators of partner innovation collaboration, management support, innovation speed, and new product performance have a factor loading estimated value greater than 0.7 and the t-statistic value is greater than t-table (1.97). Table 1 also shows convergence validity from each variable. It can be indicated by the average variance extracted (AVE) value for all variable constructs greater than 0.5 . It means all variables are valid and can be continued for the next process.

Then, we verify the discriminant validity of the measurement model through the Fornell-Larcker Criteria approach (Table 2), because the ratio for all constructs is smaller than the respective discriminant values of the construct; therefore all construct can be processed to next step.

\section{Test of Reliability}

Table 3 shows the test of reliability to check the consistency of each variable. With a minimum value is above 0.4 (Cronbach alpha should $>0.4$ ). It can be explained that all construct is reliable. Test of reliability also examines composite reliability. It can be accepted if the composite reliability value is between 0.6 to 0.7 , for a higher level, the value of 0.7 to 0.9 can be more satisfying (Hair et al. 2014). Table 3 shows that each composite reliability of all variables is above 0.7. The composite reliability value of the partner innovation collaboration is 0.883 ; management support is 0.903 ; innovation speed is 0.949 , and new product performance of 0.917 . The results of each indicator show values above 0.7 can be accepted. It means the variables in this study is reliable and can be continued for the next process.

\section{Test of The Structural Model}

Structural model testing to show the correlation values between variables, significance, and R-square values of the relationships between constructs. The PLS research model begins with knowing the R-square value of all dependent variables. This value is to determine the effect of exogenous latent variables on endogenous ones. Following Table 4, the estimated R-square value using PLS shows the value of innovation speed is 0.432 , and new product performance is 0.637 . Higher values represent a more significant influence on endogenous variables. Variable of the innovation speed has an R-square value of 0.432 , meaning that partner innovation collaboration and management support can explain $43.2 \%$ to innovation speed and other variables outside this research model determine the remaining 
$56.8 \%$. In addition, new product performance variable has an R-square value of 0.637 , meaning that partner innovation collaboration, management support and innovation speed can explain $63.7 \%$ to new product performance, other variables outside the research model determine the remaining $36.3 \%$.

\section{Hypothesis Testing}

Table 5 presents the results of measuring hypothesis testing for all variables in the research model.

Table 1 . Test of validity

\begin{tabular}{lccc}
\hline Construct & Factor Loading & t-statistic (t-table=1.97) & Description \\
\hline Partner Innovation Collaboration (AVE=0.653) & & & \\
Innovation collaboration with suppliers & 0.809 & 14.580 & Valid \\
Innovation collaboration with consumers & 0.853 & 35.642 & Valid \\
Innovation collaboration with competitors & 0.807 & 17.284 & Valid \\
Innovation collaboration with other partners & 0.761 & 14.460 & Valid \\
Management Support (AVE=0.651) & & & \\
The time provided for innovation & 0.776 & 7.726 & Valid \\
The effort and mind spent on innovation & 0.744 & 6.327 & Valid \\
Costs incurred for innovation & 0.898 & 13.485 & Valid \\
Work atmosphere that supports innovation & 0.852 & 10.749 & Valid \\
Large support to always innovate & 0.754 & 10.011 & Valid \\
Innovation Speed (AVE=0.757) & & & \\
Quick new ideas for new products & 0.868 & 29.863 & Valid \\
Rapid innovation for new products & 0.866 & 24.491 & Valid \\
Short time and efficient in innovating & 0.927 & 61.583 & Valid \\
Speed up the duration of the innovation process & 0.850 & 23.203 & Valid \\
Faster innovation than competitors & 0.878 & 29.875 & Valid \\
New products that are faster than competitors & 0.827 & 18.959 & Valid \\
New Product Performance (AVE=0.734) & & & \\
Sales volume of new products & 0.870 & 14.753 & Valid \\
Market share for new products & 0.930 & 69.283 & Valid \\
ROI of new products & 0.868 & 34.408 & Valid \\
Level of consumer acceptance of new products & 0.748 & 16.207 & Valid \\
\hline
\end{tabular}

Table 2. Discriminant validity using fornell-larcker criteria

\begin{tabular}{lcccc}
\hline Constructs & Innovation Speed & $\begin{array}{c}\text { Management } \\
\text { Support }\end{array}$ & $\begin{array}{c}\text { New Product } \\
\text { Performance }\end{array}$ & $\begin{array}{c}\text { Partner Innov. } \\
\text { Collaboration }\end{array}$ \\
\hline Innovation Speed & 0.870 & & & \\
Management Support & 0.554 & 0.807 & & \\
New Product Performance & 0.769 & 0.492 & 0.857 & \\
Partner Innovation Collaboration & 0.551 & 0.414 & 0.602 & 0.808 \\
\hline
\end{tabular}

Table 3. Test of reliability

\begin{tabular}{lccc}
\hline Variables & Cronbach Alpha & Composite Reliability & Description \\
\hline Partner Innovation Collaboration & 0.824 & 0.883 & Reliable \\
Management Support & 0.874 & 0.903 & Reliable \\
Innovation Speed & 0.935 & 0.949 & Reliable \\
New Product Performance & 0.878 & 0.917 & Reliable \\
\hline
\end{tabular}


Table 4. R-Square

\begin{tabular}{lcc}
\hline Variables & R-Square & Adjusted R-Square \\
\hline Innovation Speed & 0.432 & 0.420 \\
New Product Performance & 0.637 & 0.629 \\
\hline
\end{tabular}

Table 5. Hypothesis testing result

\begin{tabular}{lccc}
\hline Hypothesis & $\begin{array}{c}\text { Construct } \\
\text { Coefficient }\end{array}$ & $\begin{array}{c}\text { t-statistic } \\
\text { (t-table=1.97) }\end{array}$ & Description \\
\hline H1: Partner Innov. Collab. $\rightarrow$ Innovation Speed & 0.389 & 4.854 & Supported** \\
H2: Management Support $\rightarrow$ Innovation Speed & 0.393 & 5.987 & Supported $^{* *}$ \\
H3: Innovation Speed $\rightarrow$ New Product Perf. & 0.628 & 8.492 & Supported** $^{*}$ \\
H4: Partner Innov. Collab. $\rightarrow$ New Product Perf. & 0.256 & 3.307 & Supported** \\
\hline
\end{tabular}

Notes: ${ }^{* *}$ Sig. $<0.01$

\section{Partner Innovation Collaboration on Innovation Speed}

The result of the path analysis estimate is 0.389 . That value indicates that partner innovation collaboration positively affects innovation speed. A test result of hypothesis can prove sig. $<0.01$ (t-statistic 4.854 ), and this means that better partner innovation collaboration, better innovation speed will be. Therefore, it can be concluded that there is a positive and significant influence from the role of partner innovation collaboration toward innovation speed. This result supported by Santos-Vijande et al. (2016) explained that partner innovation collaboration allows appropriate responsiveness to market demands, preventing delays, and enhancing innovation speed. This result is consistent with research that state the positive impact of PIC on partner's innovation adoption and their readiness to encourage a new product which speeds up new product release and minimizes time to market. In that way, PIC provides an important knowledge interface enabling firms to maintain speed with the fast market evolution and also to improve new product commercialization (Santos-Vijande et al. 2016). Based on Wang \& Wang (2012), using PIC around business sectors, firms can emphasize innovation speed and maximize their market share. When creating or launching new products faster than its rivals, a firm can build a market segment and maintaining efficiency because the information within this PIC is unavailable to rivals.

\section{Management Support on Innovation Speed}

The output value of the path analysis estimate is 0.393 , and the coefficient value is positive. It shows that better implementation of management support is, better innovation speed will be. It can be proven with the results of testing the hypothesis sig. $<0.01$ ( $t$-statistic 5.987). Therefore, it can be concluded that there is a significant and positive influence of managementsupport toward innovation speed. This finding is supported by Carbonell \& Rodríguez-Escudero (2009) state that in the situation of increased environmental turbulence, firm management can support innovation speed by giving psychological protection, empowerment, commitment, and creating a team capacities of controlling uncertainty. Basically, the accomplishment of innovation within a faster time strongly determined by management support. Top managers can improve successful new product development by supporting and providing an exciting atmosphere to encourage a research group in an organization. Furthermore, this result is appropriate with another research that identified the impact of management support is significant on innovation speed (Hamdi et al. 2016). The accomplishment of innovation the identified time is determined by management support. Top managers can support successful NPD by stimulating and providing an exciting atmosphere to promote firm research (Martín-Rojas et al. 2013).

\section{Innovation Speed on New Product Performance}

The table shows that innovation speed positively affects new product performance with a t-statistic value of 8.492 and sig. $<0.01$. The path analysis of the sample estimate is 0.628 . It means that better implementation of innovation speed will improve new product performance. Therefore, it can be concluded that there is a positive and significant effect of innovation speed toward new product performance. This finding is consistent with Carbonell \& Rodríguez Escudero (2010) states that market-oriented firm can achieve 
a new product performance caused by excellence in innovation speed and market entry. Shan et al. (2016) found that faster innovation can lead to superior new product performance. The relationship between innovation speed and new product performance is U-inverted, where the acceleration of product development can improve performance by reducing costs to a certain point, which can shorten cycle times and increase costs for firms (Langerak \& Hultink, 2006). A firm that has a strong entrepreneurial orientation view innovation speed as the core capability of their business, firms can increase IS in a turbulent market environment through investment and ongoing attention to product development that impact on superior new product performance (Shan et al. 2016).

\section{Partner Innovation Collaboration on New Product Performance}

The table shows that partner innovation collaboration positively affects new product performance with a t-statistic value of 3.307 and sig. $<0.01$. The path analysis of the sample estimate is 0.256 . It means that better implementation of partner innovation collaboration will increase new product performance. Studies conducted by previous researchers show that firms improve new product performance by interacting and collaborating with different innovation partners, such as suppliers, customers, competitors, and research institutions (Tsai, 2009). Firms that collaborate with customers in the product development process are often associated with positive new product performance because it helps firms get new ideas, provide solutions about products, recognize customer needs and predict trends in the market (Brettel \& Cleven, 2011). Firms that collaborate with suppliers tend to contribute to innovation by increasing knowledge about technology, reducing costs, increasing capabilities, improving the design process, and maintaining important supplies for firms that support new product performance (Belderbos et al. 2015). Firms that collaborate with competitors often have the same interests in product and process development, so that knowledge from competitors can also apply to these firms. Therefore, collaborative research and development with competitors can increase knowledge for firms and also improve innovation and new product performance (Kang \& Kang, 2010).

The results of investigating data using SmartPLS revealed that the structural model explains the correlation between constructs. Following bootstrapping, the output shows the structural model test from a partner innovation collaboration, management support, innovation speed, and new product performance (See Figure 2).

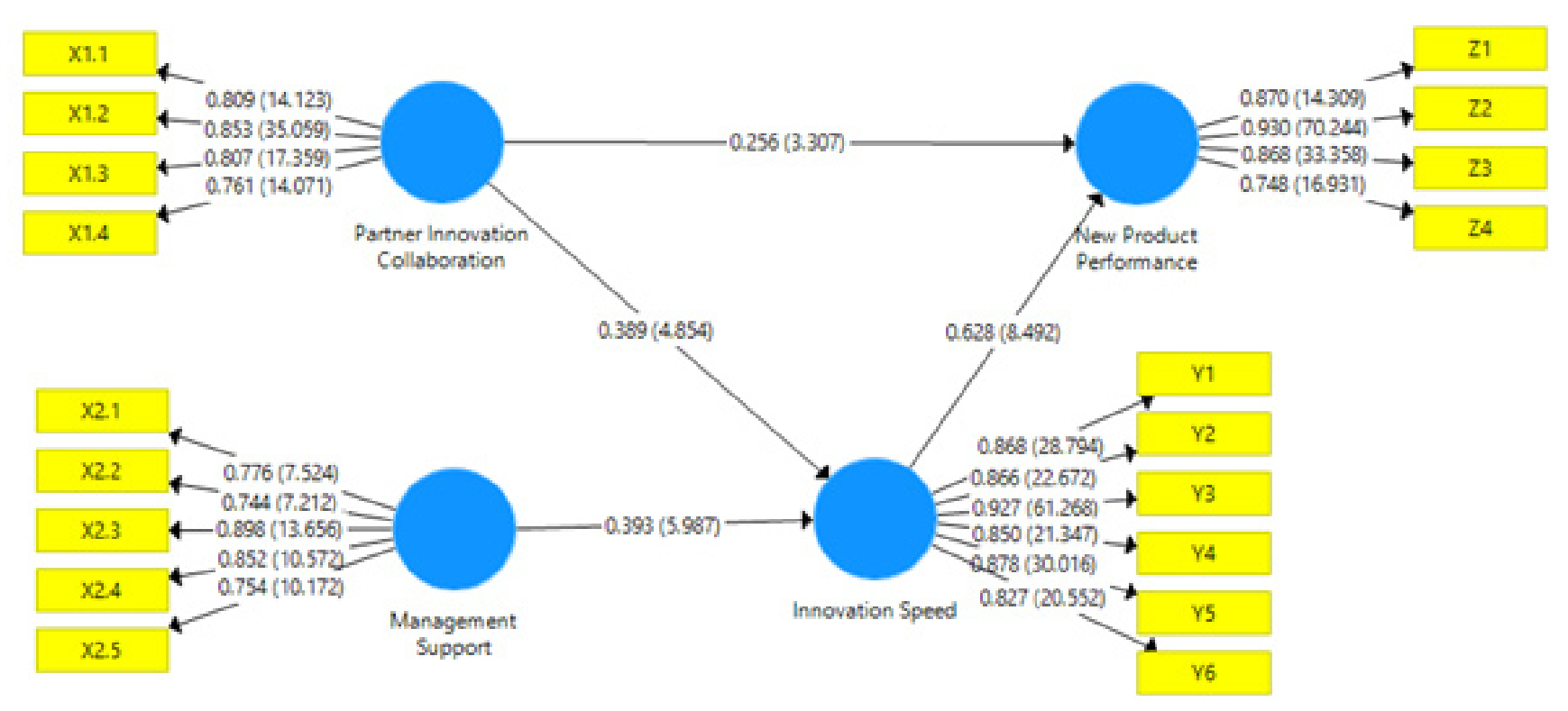

Figure 2. Structural model test 


\section{Managerial Implications}

The findings of this study have essential implications for managerial practice in small manufacturing firms. First, for small manufacturing firms, it is better to utilize an innovation collaboration with partners either with one or more of the existing partners, such as suppliers, distributors, competitors, customers, or research and education institutions. That is due to the increasing strength of competition in the manufacturing industry and consumer preferences that often change so that a higher level of product uniqueness and a faster level of innovation will be significant for small manufacturing companies. It is consistent with the results of research shows that from various types of collaborative innovation partners can help achieve the speed of innovation expected and ultimately towards improving the performance of new products for small manufacturing firms. Second, the firm's management should allocate more time, effort, thought, costs in the effort to innovation, and be able to create an atmosphere of work together with employees that support innovation activities. That is important because the role of management support can accelerate the innovation process and also indirectly have an impact on improving new product performance.

\section{CONCLUSIONS AND RECOMMENDATIONS}

\section{Conclusions}

The results of this study found that partner innovation collaboration, such as suppliers, distributors, competitors, customers, or education institutions, can increase innovation speed, and create better new product performance in small manufacturing firms. In addition, management support in allocating costs, time, energy, thoughts for innovation, and creating a work atmosphere that supports innovation activities can also increase innovation speed, and indirectly can improve new product performance. Partner innovation collaboration and management support together account for $43.2 \%$ on innovation speed. Then, partner innovation collaboration and innovation speed together resulted in $63.7 \%$ on the increase in new product performance. The variable of management support has a slightly more significant effect on innovation speed when compared to the variable of partner innovation collaboration, while innovation speed has a far more significant influence on new product performance when compared to partner innovation collaboration.

\section{Recommendations}

Small manufacturing firms should take advantage of an innovation collaboration with partners, especially with consumers because it has the most influence compared to collaborating with suppliers, competitors or other partners in increasing innovation speed and new product performance. In addition, management support can also increase innovation speed, especially in allocating costs to innovate and create a work atmosphere that supports innovation because these factors have the most dominant influence over other dimensions for small manufacturing firms. Then, the recommendation for further research is to generalize a larger population elsewhere and to research in other sectors outside of manufacturing companies. The study also recommends including moderation variables that support the improvement of new product performance such as absorptive capacity and technological uncertainty.

\section{ACKNOWLEDGEMENT}

The author thanks Direktorat Riset dan Pengabdian Masyarakat, Direktorat Jenderal Penguatan Riset dan Pengembangan Kementerian Riset, Teknologi dan Pendidikan Tinggi Republik Indonesia for funding this research through project number 110/SP2H/PPM/ DRPM/2019, 8 March 2019.

\section{REFERENCES}

Atkinson R, Crawford L, Ward S. 2006. Fundamental uncertainties in projects and the scope of project management. International Journal of Project Management 24(8): 687-698.

Belderbos $\mathrm{R}$ et al. 2015. Inter-temporal patterns of $R \& D$ collaboration and innovative performance. Journal of Technology Transfer 40(1): 123-137.

Bisnis.com. 2014. Mencegah Stagnasi Ekonomi Kreatif. Retrieved from http://bandung.bisnis. com/read/20140925/82446/519060/mencegah- 
stagnasi-ekonomi-kreatif

BPS. 2016. Grafik Sensus Ekonomi 2016 Indonesia. Retrieved August 30, 2019, from https://se2016. bps.go.id/umkumb/

Brettel M, Cleven NJ. 2011. Innovation culture, collaboration with external partners and NPD performance. Creativity and Innovation Management 20(4): 253-272.

Carbonell P, Rodríguez-Escudero AI. 2009. Relationships among team's organizational context, innovation speed, and technological uncertainty: An empirical analysis. Journal of Engineering and Technology Management 26(1-2): 28-45.

Carbonell P, Rodríguez Escudero AI. 2010. The effect of market orientation on innovation speed and new product performance. Journal of Business \& Industrial Marketing 25(7): 501-513.

Chandra AA. 2016. Ini Kendala yang Dihadapi Pelaku Industri Kreatif. Retrieved from https://finance. detik.com/berita-ekonomi-bisnis/d-3284282/inikendala-yang-dihadapi-pelaku-industri-kreatif

Chen J, Reilly RR, Lynn GS. 2005. The Impacts of Speed-to-Market on New Product Success: The Moderating Effects of Uncertainty. IEEE Transactions on Engineering Management 52(2): 199-212.

Chen J, Damanpour F, Reilly RR. 2010. Understanding antecedents of new product development speed: A meta-analysis. Journal of Operations Management 28(1): 17-33.

Chiang YH, Hung KP. 2010. Exploring open search strategies and perceived innovation performance from the perspective of inter-organizational knowledge flows. $R$ and $D$ Management 40(3):292-299.

Cook C, Heath F, Thompson RL. 2000. A metaanalysis of response rates in web-or internetbased surveys. Educational and Psychological Measurement 60(6): 821-836.

Cravens DW, Piercy N. 2013. Strategic Marketing (Tenth Edit). New York: McGraw-Hill.

Du Plessis M. 2007. The role of knowledge management ininnovation. Journal ofKnowledge Management 11(4): 20-29.

Fabrizio, K. R. (2009). Absorptive capacity and the search for innovation. Research Policy 38(2):255-267.

Ghozali, I. (2011). Structural Equation Modeling: Concepts and Applications with AMOS Program Ver. 16. Semarang: Publisher Agency Diponegoro
University.

Griffin RW. 2011. Management: Principles and Practices (10th ed.). Boston, MA: South-Western Cengage Learning.

Hagedoorn J. 2002. Inter-firm R\&D partnerships: an overview of major trends and patterns since 1960. Research Policy 31(4): 477-492.

Hair JFJ, Hult GTM, Ringle C, Sarstedt M. 2014. A Primer on Partial Least Squares Structural Equation Modeling (PLS-SEM). Long Range Planning.

Hamdi S et al. 2016. Impact of T-shaped skill and top management support on innovation speed; the moderating role of technology uncertainty. Cogent Business \& Management 3(1).

Kang KH, Kang J. 2010. Does partner type matter in R\&D collaboration for product innovation? Technology Analysis and Strategic Management 22(8): 945-959.

Kim CS, Inkpen AC. 2005. Cross-border R\&D alliances, absorptive capacity and technology learning. Journal of International Management 11(3): 313-329.

Langerak F, Hultink EJ. 2006. The impact of product innovativeness on the link between development speed and new product profitability. Journal of Product Innovation Management 23(3): 203214.

Markman GD etal. 2005. Innovation speed: Transferring university technology to market. Research Policy 34(7): 1058-1075.

Martín-Rojas R et al. 2013. Influence of technological support, skills and competencies, and learning on corporate entrepreneurship in European technology firms. Technovation 33(12): 417430.

Rizal M. 2014. Kadin: Empat kendala penghambat pengembangan UMKM. Kabarbisnis.Com. Retrieved from http://www.kabarbisnis.com/ $\mathrm{read} / 2845011$

Santos-Vijande ML, López-Sánchez JÁ, Rudd J. 2016. Frontline employees' collaboration in industrial service innovation: routes of co-creation's effects on new service performance. Journal of the Academy of Marketing Science 44(3): 350-375.

Shan P, Song M, Ju X. 2016. Entrepreneurial orientation and performance: Is innovation speed a missing link? Journal of Business Research 69(2): 683690.

Sidarta KL, Oktaviani R, Kirbrandoko K. 2016. STRATEGI PENINGKATAN DAYA SAING 
PT 'ABCD' TBK. DI INDUSTRI MAKANAN

OLAHAN PADA TAHUN 2015. Jurnal Aplikasi

Bisnis dan Manajemen 2(1): 73.

Tsai KH. 2009. Collaborative networks and product innovation performance: Toward a contingency perspective. Research Policy 38(5): 765-778.

Wang G, Dou W, Zhu W, Zhou N. 2015. The effects of firm capabilities on external collaboration and performance: The moderating role of market turbulence. Journal of Business Research 68(9):1928-1936.

Wang Z, Wang N. 2012. Knowledge sharing, innovation and firm performance. Expert Systems with Applications 39(10): 8899-8908. 